\title{
Labour
}

Journal of Canadian Labour Studies

Le Travail

Revue d'Études Ouvrières Canadiennes

\section{Labour in Need of Revolutionary Vision}

\section{Jim Selby}

Volume 83, printemps 2019

URI : https://id.erudit.org/iderudit/1061041ar

DOI : https://doi.org/10.1353/1lt.2019.0009

Aller au sommaire du numéro

Éditeur(s)

Canadian Committee on Labour History

ISSN

0700-3862 (imprimé)

1911-4842 (numérique)

Découvrir la revue

Citer ce document

Selby, J. (2019). Labour in Need of Revolutionary Vision. Labour / Le Travail, 83, 233-246. https://doi.org/10.1353/llt.2019.0009 d'utilisation que vous pouvez consulter en ligne.

https://apropos.erudit.org/fr/usagers/politique-dutilisation/ 


\section{PRESENTATION / PRÉSENTATION}

\section{Labour in Need of Revolutionary Vision}

\section{Jim Selby}

THE LABOUR MOVEMENT'S INABILITy to effectively respond to neoliberalism has resulted in reduced union membership and declining public status and influence of labour unions. This is having a cascading effect on other institutions that are at least peripherally linked with the working class, from the rightward march of social democratic parties to the move away from class as the foundation of labour history. I suggest that the absence of revolutionary unions, those fighting for a future beyond capitalism, is one of the key underlying causes of labour's current malaise. By revolutionary unions, I mean unions that are explicitly pro-socialist and anti-capitalist in intent and that, by their actions and by the response of capital and state to those actions, foster an awareness of the class nature of society, the specific interests of working people as a class, and possibilities for collectively pursuing a better future.

\section{The Labour Movement in Crisis}

THE BUSINESS UNION MODEL is failing. The strategy of developing relationships, bargaining or otherwise, and struggling for workers' rights within capitalism has yielded fewer and fewer benefits to workers since the early 1970s. Considering the constant bubbling up of workers' discontent and militancy engendered by continuous conflicts with management over control of work, it is hard to understand why union representation continues to drop. It is not as if bosses have suddenly become more benevolent, yet the rate of unionization in Canada fell from 37.6 per cent in 1981 to 28.8 per cent in $2014 .^{1}$

For a union strategy that measures success based upon protecting job tenure and expanding, or at the very least protecting, existing levels of wages and

1. Statistics Canada, “Unionization Rate Falling," modified 17 May 2018, https://www150. statcan.gc.ca/n1/pub/11-630-x/11-630-x2015005-eng.htm. 
benefits, the last 40 years have been a protracted and losing engagement with employers. The relocation of manufacturing jobs to low-wage countries and technological change in resource extraction industries are part of the reason for declining union membership, as are the privatization, contracting out, and reduction of public-sector jobs. Although 75.5 per cent of public employees were covered by a collective agreement in 2017, only 16.4 per cent of privatesector employees had union coverage. ${ }^{2}$

In the United States, the picture is even grimmer. In 2010, fifteen years after the vaunted movement from business unionism to social unionism, American unions had one million fewer members than they had in $1995 .{ }^{3}$ Nor is the picture different in other developed economies. Across Europe, trade union membership has been declining, most markedly among young workers. ${ }^{4}$ In Britain, Richard Hyman observed in 2012 that half of union members would retire within a decade and that fewer than 10 per cent of young workers were unionized. ${ }^{5}$ This decline in Britain has been accompanied by a sharp decrease in militancy. From 2000 to 2014, as John McIlroy has observed, overall strike activity in Britain hit a recorded nadir. One-day work stoppages, mostly in the public sector, were the norm and more aggressive, and united action was almost non-existent. McIlroy notes that after the unparalleled decline of union membership between 1979 and 1996, another steep decline occurred between 2000 and 2011, "at which point 75 per cent of workers were no longer trade unionists." 6

The problem is that the union movement as it is currently constituted is not able to protect its members from a corporate offensive that began in the mid-1970s and has continued to this day. Labour has been unable to protect good jobs or to make bad jobs better. Do not mistake this for a blanket criticism of trade unions. There is no doubt that rank-and-file union members are better off in terms of working conditions, wages, and benefits than they would have been without unions. However, the narrow focus of the modern labour movement on gains within market capitalism makes it incapable of mounting

2. Statistics Canada, "Union Status by Industry," table 14-10-0132-01.

3. Richard Sullivan, "Why the Labor Movement Is Not a Movement," New Labor Forum 19, 2 (2010): 53.

4. Kurt Vandaele, "How Can Trade Unions in Europe Reconnect with Young Workers?," in Jacqueline O’Reilly, Clémentine Moyart, Tiziana Nazio \& Mark Smith, eds., Youth Employment: STYLE Handbook (Brighton: Crome, 2017), 49-52, https://style-handbook.eu/contents-list/ young-peoples-attitudes-and-values/how-can-trade-unions-in-europe-reconnect-withyoung-workers/.

5. Richard Hyman, "Will the Real Richard Hyman Please Stand Up?," Capital E Class 36, 1 (2012): 153.

6. John McIlroy, "Marxism and the Trade Unions: The Bureaucracy versus the Rank and File Debate Revisited," Critique 42, 4 (2014): 523. 
a serious challenge to the degradation of work. The growth of part-time, temporary, and term work in both the public and private sectors make that clear.

There is a suggestion that the problem goes back to the labour accord signalled by the Wagner Act in the United States and PC 1003 in Canada. In exchange for union recognition, the labour movement agreed to engage in a legal-technical industrial relations system that ceded control of work to employers, directed bargaining into compensation issues, and limited spontaneous rank-and-file actions. However, there was more to that bargain than the legitimation of unions and union contracts. The leadership of the labour movement in both the United States and Canada also proved it was trustworthy by actively participating in the Cold War, expelling and blacklisting communists and socialists, and abandoning any discussion of class struggle. ${ }^{7}$

The irony is that it took the active participation of the labour movement in the Red Scare following World War II to suppress revolutionary unions and revolutionaries within unions - something the Canadian state and employers had been attempting to do unsuccessfully since the turn of the 20th century. ${ }^{8}$ Canadian state complicity in the raiding and destruction of the Canadian Seaman's Union illustrates the continued state policy of suppression of radical unions and the willingness of employers and business unions to do the dirty work. However, the triumph of the business unionists and their allies in the political arena came with unexpected consequences. The resulting conservatism of the labour movement leadership served to separate union bureaucracy from the upsurge of radical rejection of capitalism in the 1960s. Young workers defied the authority of both employers and unions in a wave of wildcat strikes. They were an integral part of the countercultural movement that rejected the sterility of life and work under capitalism. ${ }^{9}$ The labour movement's attempts to suppress young workers would leave them more vulnerable to the rise of neoliberalism in the coming decades. According to Kim Moody, the struggle between young militant workers and union leaders "exhausted both sides and left the leadership unable to mobilize the ranks" to resist the assaults of the 1970s and 1980s. ${ }^{10}$

7. Brian Green, "Organizing for Defeat: The Relevance and Utility of the Trade Union as a Legitimate Question," Labour/Le Travail 62 (Fall 2008): 163.

8. For a detailed look at how employers and the state encouraged "responsible" unions and discouraged revolutionary unions, see Judy Fudge \& Eric Tucker, Labour Before the Law: The Regulation of Workers' Collective Action in Canada, 1900-1948 (Toronto: University of Toronto Press, 2001).

9. Bryan D. Palmer, Canada's 1960s: The Ironies of Identity in a Rebellious Era (Toronto: University of Toronto Press, 2009), 211-241.

10. Kim Moody, "Contextualising Organised Labour in Expansion and Crisis: The Case of the US," Historical Materialism 20, 1 (2012): 5, 6. 


\section{The Long Employer Offensive}

FROM THE MID-1970s, signalled by either the formation of an overarching voice of capital in Canada, the Business Council on National Issues (1976), or by the Trudeau government's explicit rejection of free collective bargaining with the implementation of wage and price controls (1975), a long capitalist offensive against working-class gains began. ${ }^{11}$ Unfortunately, North American trade unions had fitted themselves into a tripartite model that eschewed worker mobilization and direct action, and they had "disavowed solidarity with workers in the Third World and with huge numbers of potential allies at home in order to win favour with the Cold Warriors of North American political administration."12 As activist Bill Fletcher Jr. bluntly puts it, with a tamed incorporated labour movement, "the dominant sectors of capital (and their political allies) no longer see any particular need for compromise with the working class." 13

In the collective bargaining system, concession bargaining since the 1970s - often under the threat (and then the implementation) of business relocation to low-wage jurisdictions - eroded hard-won gains in wages, benefits, and pensions for union members in the private sector. In the public sector, the threat was not relocation, but rather contracting out and privatization. Inevitably, despite concessions, plant closures and contracting out continued to take place. This form of attack on workers continues to be used by employers to this day.

As good secure jobs have become scarcer, work has also become more intense. In Britain, a study by Francis Green shows substantial increases in the factors inducing hard work from employees between 1986 and $1997 .{ }^{14}$ Among those factors identified by Green were an increase in the number of people working more than 48 hours per week, an increase in average household hours worked, and the elimination of gaps between tasks where mind and body rest resulting from the implementation of team-working methods, just-in-time, and total quality management techniques. I remember doing an interview with a 60-year-old, long-time Gainers meatpacking worker in 1987. The line had been sped up over and over, and forced overtime had become so prevalent that he literally did nothing at home except eat and go to bed.

This new aggressive assault on unions signalled the end of the postwar peace accords and the start of the neoliberal era. The burning question is why was

11. David Langille, "The Business Council on National Issues and the Canadian State," Studies in Political Economy 24, 1 (1987): 41-85.

12. Green, "Organizing for Defeat," 163.

13. Fletcher, "A New Brand of Unionism," New Labor Forum 25, 1 (2016): 15.

14. Francis Green, "It's Been a Hard Day's Night: The Concentration and Intensification of Work in Late Twentieth-Century Britain," British Journal of Industrial Relations 39, 1 (2001): 75-76. 
the labour movement so incapable of defending itself? Employers have torn up the peace accord, but unions have persisted in following the old rules, unwilling or unable to abandon their dependence on a legal system that employers have jettisoned.

Union leaders have been singled out as an obstacle to effective struggle by workers against neoliberalism. ${ }^{15}$ Their overweening interest in stability and continuity of the organization outweighed the need for a militant response. This criticism has been extended to union bureaucracy - made up of fulltime officers and staff of unions. While there is no doubt that self-interest and careerism blunt the appetite of some union leaders and staff for radical struggle, the lack of effective labour response to neoliberalism goes far beyond critiques of union bureaucracy. ${ }^{16}$ The worst of business unions are authoritarian and non-inclusive, but even the best, the so-called social union variety, have democratic deficits in terms of gender, race, and ethnicity and are still enmeshed within the capitalist system. ${ }^{17}$ That system is powerfully constraining. As Alberta Union of Provincial Employees (AUPE) president Guy Smith observed, "even with the best intentions it is hard for unions to escape the straitjacket of rules and narrowly defined acceptable behaviours, despite a clear understanding that the system isn't working." 18

Simply put, only a union movement prepared to fight for a future beyond capitalism, to mobilize against the very notion that the market is an appropriate vehicle for any decision-making, would be able to confront neoliberalism. Yes, there are union leaders who support radical labour responses. The problem is that even the most willing of leaders is situated in organizations thoroughly mired in the capitalist industrial relations system. So long as unions and union leaders are unwilling to escape from the shackles of legality and "responsible unionism" they will be unable to come to grips with the causes of union decline.

\section{The Crisis in Social Democratic Parties}

IT IS NOT ONLY UNIONS that have accommodated themselves to capitalism to a point where they can no longer effectively fight against it: their post-World War II political voice, the social democratic parties, are also increasingly

15. Ralph Darlington \& Martin Upchurch, "A Reappraisal of the Rank-and-Rile versus Bureaucracy Debate," Capital \& Class 36, 1 (2012): 91.

16. For an examination of union bureaucracy, see David Camfield, "What Is Trade Union Bureaucracy? A Theoretical Account," Alternate Routes: A Journal of Critical Social Research 24 (2013): 133-155; McIlroy, "Marxism and the Trade Unions."

17. Green, "Organizing for Defeat," 166-167. For a more positive examination of social unionism, see Stephanie Ross, "Social Unionism and Membership Participation: What Role for Union Democracy?," Studies in Political Economy 81, 1 (2008): 129-157.

18. Guy Smith, personal communication to author, 4 April 2018. 
unwilling or unable to oppose neoliberalism. When Dave Barrett, premier of British Columbia from 1972 to 1975, allegedly said that his New Democrat Party (NDP) government would save capitalism from itself, it was a sign of how far the successor to the Co-operative Commonwealth Federation (CCF) had already strayed from its origins as a party committed to a democratic transition to socialism. Much of that ideological journey took place against the background of the Cold War, during which the social democrats participated in the Red Scare within the labour movement and in their electoral strategies. ${ }^{19}$

Despite that drift from a revolutionary program to a reformist program, social democrats in Canada and Europe extracted major gains in social welfare from the state in the post-World War II boom. The working class gained access to health care, post-secondary education, unemployment insurance, pensions, and other social welfare programs. Full employment seemed an attainable goal. The trappings of the welfare state supported the idea that capitalism could be gradually reformed and transformed.

That illusion began to fade in the mid-1970s. High inflation, slow economic growth, and high unemployment opened the door to business prescriptions for "counter-inflationary austerity, welfare state retrenchment, privatisation and deregulation." ${ }^{20}$ The answer to labour's gains in the 1950s and 1960s was deindustrialization as corporations moved production to low-wage countries. In Canada, as elsewhere, the welfare state was unravelled. Unemployment insurance became increasingly restricted, social welfare programs were cut back, fees were instituted for health care, and post-secondary tuition rates rose dramatically.

Even the Scandinavian countries, long a symbol of the success of welfare capitalism, retrenched. The welfare state in the Nordic countries "is increasingly becoming an object of nostalgia rather than a living political reality." 21 Finance has been deregulated and public services privatized. By the mid1990s, key social democratic parties in the Socialist International, led by Tony Blair's Labour Party's Third Way in Britain, accepted neoliberal policies. In Germany, Italy, and Portugal, social democratic governments "initiated deep cuts in public expenditure, made labour relations more precarious, implemented policies of wage 'moderation,' and liberalized markets and services." ${ }^{22}$

If anything, the social democratic governments were better at bringing in neoliberal policies than pro-capitalist governments were; according to

19. Irving Martin Abella, Nationalism, Communism, and Canadian Labour: The CIO, the Communist Party, and the Canadian Congress of Labour, 1935-1956 (Toronto: University of Toronto Press, 1973).

20. John Callaghan \& Nina Fishman, In Search of Social Democracy: Responses to Crisis and Modernisation (Manchester: Manchester University Press, 2010), 1-6.

21. Teppo Eskelinen, “The Nordic Radical Left," Socialism and Democracy 29, 3 (2015): 115.

22. Marcello Musto, "The Post-1989 Radical Left in Europe: Results and Prospects," Socialism and Democracy 31, 2 (2017): 3, 4. 
Marcello Musto, "the trade unions found the government actions more acceptable because of an old illusory belief that they were 'friendly' to the labour movement." ${ }^{23}$ In fact, the labour movement has been well aware of the drift to the right in social democratic parties. But, in the absence of a radical alternative, where else could labour throw its support? For example, in Alberta, the New Democratic government has convinced/compelled public-sector unions and workers to accept wage freezes over the past two years. Would the nurses, teachers, healthcare workers, and provincial employees have accepted that from a Conservative government? Not without a struggle. The rationale for union acquiescence is fairly clear, as AUPE president Guy Smith notes: "We gained some historic contract language, but it still rankles that our members took a real wage cut from the NDP government, even though we know things would be worse under a Liberal or Conservative government." ${ }^{24}$

A more disturbing argument suggests that the labour movement was a willing partner with social democratic parties in the creation of neoliberalism. In Australia, for instance, Elizabeth Humphrys and Damien Cahill argue, "by the end of Australia's longest ever period of social democratic governance, a radical neoliberal restructuring of the state and economy had been affected and it was at least as nationally far-reaching as the contemporaneous neoliberal changes made under Reagan and Thatcher." They charge that the leaders of the Australian movement "were complicit in processes of workplace neoliberalisation." ${ }^{25}$ Humphrys and Cahill point out that the accord negotiated between the successive Labor governments and the Australian Council of Trade Unions between 1983 and 1996 froze real wages, following which the government negotiated a free trade deal, deregulated the financial sector, floated the Australian dollar, and ultimately turned its back on promises of more progressive taxation and public investment.

If not directly complicit in the advent of neoliberal reforms, the American labour movement certainly had a long history - since the 1960s - of acquiescing to wage concession and workplace restructuring demands by employers and the simultaneous suppression of militant rank-and-file demands. When labour did oppose early neoliberal initiatives like Democratic Party president Jimmy Carter's airline, trucking, and railway deregulation, they were unsuccessful. Furthermore, when it came to direct assaults on workers by neoliberal governments - for example, Ronald Reagan's dismissal of over 11,000 air traffic controllers to crush the Professional Air Traffic Controllers Organization (PATCO) strike in 1981 - the labour movement proved unable or unwilling to mount effective opposition. The subsequent rolling out of the marketization of society through privatization, deregulation, public service cutbacks,

23. Musto, "Post-1989 Radical Left," 4.

24. Guy Smith, personal communication to author, 11 September 2018.

25. Humphrys \& Cahill, "How Labour Made Neoliberalism," Critical Sociology 43, 4/5 (2017): 671. 
tax breaks for the wealthy, and globalization of production met with similarly ineffectual labour responses.

With labour leaders unable to resist the dismantling of the welfare state, it is unsurprising that their ostensible political arms were unable to do so either. The social democratic parties most responsible for the working-class gains of the welfare state were incapable of defending it, and in many cases have helped dismantle it.

\section{Union Decline and Labour Historians}

THE LINK BETWEEN UNIONS and labour historians is both obvious and subtle. Unions are the most visible, prevalent, and effective form of working-class organization, and certainly the one most associated with the struggle between the working class and capital. As such, unions are an obvious focus of labour historians. Moreover, unlike those in other academic fields, many labour historians have also been left activists of various stripes. In a very real sense, the underlying premise of this article is that it is the abandonment or eclipse of radical class-based unionism by business unions committed to incremental success under capitalism that has undermined and enfeebled the labour movement. That same might be said of labour history in terms of the differences of approach to the subject between social democratic and Marxist/radical historians. Radical labour historians are marked by their broader engagement with society. Or, to be more precise, their research is intended to encourage anticapitalist critiques and to foster radical social change. ${ }^{26}$

The debate between radicals who try to extend union struggle within the system to struggles against the system and those who accept the basic underpinnings of capitalism has been a historic feature of the Canadian labour movement. An engaged, radical trade union movement underscores the importance of labour history; a quiescent, incorporated labour movement does the opposite. It should be no surprise, then, that the decades-long "erosion of trade unionism and social democracy, and the virtual extinction of 'official Communism"' have caused a decline in labour history as an academic discipline. ${ }^{27}$ McIlroy places the decline of labour history squarely on the decline of the labour movement itself. He argues that just as "a rising labor movement provided inspiration and impetus" for labour historians' work and strengthened their identity, the reverses that organized labour has

26. Chad Pearson, “Twentieth Century US Labor History: Pedagogy, Politics, and Controversies Part 1," History Compass 15, 12 (2017): 1-11; Andrew Wells, "Familiar Cul-deSacs: Conference of the Society for the Study of Labour History, Birkbeck College, London, Spring 1990," History Workshop, no. 30 (1990): 229-233.

27. John McIlroy, "Waving or Drowning? British Labor History in Troubled Waters," Labor History 53, 1 (2012): 93. 
experienced under neoliberalism have "bred distance or defection." ${ }^{28}$ The decline of unions and their diminished role in society is only one of the ways neoliberalism has impacted labour historians. The intrusion of neoliberal policies into post-secondary education, marked by overall funding cuts and an emphasis on university education as job training, has also had a pronounced effect on labour history as a discipline. McIlroy suggests that labour history in Britain encountered specific funding issues related to neoliberal hostility to working-class organization. He observes that there were fewer opportunities in labour history and that this drove people away from the field to novel and "sexier" academic pursuits. ${ }^{29}$ The low ebb in labour history in Canada has been observed in the paucity of labour history panels at meetings of the Canadian Historical Association (CHA). Of a total of 102 panels at the 2015 CHA meeting, only 5 mentioned labour history-specific topics. ${ }^{30}$

\section{An Argument for Revolutionary Unions}

The CORE ARgument of this paper is that it was the Cold War purging of socialist, syndicalist, and communist radicals and the continued suppression of revolutionary unions that left conservative business union leaders at the helm of the labour movement and rendered the movement incapable of confronting neoliberal reforms. The kind of massive mobilizations of workers that would be required to counter the capitalist offensive of the 1970s and 1980s were not within the repertoire of business unionists for three reasons. First, the practice of business unionism alienates rank-and-file members by attempting to channel the broad interests of workers in the workplace into narrow economic terms while ceding all of the critical decision-making power to management. Business unionism, which saw its primary mission as maximizing members' wages, benefits, and job security, had no answer to the deep dissatisfaction of a more educated generation of young workers with the increasingly tedious nature of work created by automation and technological change.

To illustrate: For several years, I taught an "Introduction to the Union" weekend course for a local labour council. I always ended the course by breaking workers into cross-occupational groups and asking them to reach consensus on what they would most like their union to negotiate for them with no limitations except their imaginations. Wages and benefits did not even enter their discussions. More flexible work time, more educational opportunities, more control over how and when they did their work, real-time protection

28. McIlroy, "Waving or Drowning?," 97.

29. McIlroy, "Waving or Drowning?," 91-119.

30. Christo Aivalis, Greg Kealey, Jeremy Milloy \& Julia Smith, "Back to Work: Revitalizing Labour and Working-Class History in Canada," Active History, 21 September 2015, http:// activehistory.ca/2015/09/back-to-work-revitalizing-labour-and-working-class-historyin-canada/. 
from bad bosses, and the ability to say "no" to their boss at work were typically their priorities. Given how little the modern collective agreement - with its ceding of management authority, and obey now/grieve later rules - meets workers' real needs at work, it is small wonder that unions struggle to reach meeting quorums of 5 per cent at membership meetings, let alone getting the majority out on the streets.

The second barrier that business unions face in confronting neoliberalism is their ideology. By rejecting radical critiques of capitalism and positioning themselves as responsible unions willing to cooperate with employers and the state to maintain stability and competitiveness, business unions discouraged challenges to the industrial relations system. Wildcats and political strikes are discouraged or, as in the case of the Canadian Labour Congress' "Day of Protest" over wage and price controls, channelled into purely symbolic protests. By confining their struggles within capitalism, the labour movement had little ability to withstand the market forces that are an essential component of the system. Just how far business unions have removed themselves from class conflict can be seen by how few labour leaders ever refer to the working class often preferring a mystifying reference to a "middle class" when talking about their members.

A third barrier to business union action against neoliberalism is structural. Union officers and staff have a vested interest in the ongoing organizational and financial integrity of their unions. That is not a bad thing in itself. However, when the personal well-being of officers promotes careerism and encourages conservative tactics, then it is a problem. Given the long history of the state's and employers' intolerance of radical unions, business union bureaucracy has grounds to fear committing to radical actions, even when such actions are called for.

In short, business unions cannot and will not engage in the kind and level of struggle necessary to confront neoliberalism. The transformation of work into "a more alienated, fractured and individualized" experience demands a labour movement focused on goals broader than old-style labourist thinking. ${ }^{31}$ Realistically, the only way forward for working people requires turning away from the current business union model that is so caught in the past and enmeshed in the capitalist state. That would also entail turning away from the business unions' political vehicle: social democratic parties. Since those parties have proven ineffective at protecting workers and unions, or of even maintaining their traditional reformist ideologies, this should not be a difficult task for working people.

The creation of a new, vibrant labour movement would require either the transformation of our present unions into something other, or the creation of a

31. Christopher Lloyd \& Tony Ramsay, "Resisting Neo-Liberalism, Reclaiming Democracy? 21st-Century Organised Labour beyond Polanyi and Streeck," Economic and Labour Relations Review 28, 1 (2017): 129. 
new revolutionary unionism. This is because, as Hyman so pointedly observed, "it is hard to envisage a movement for social transformation in which unions do not form a part. But this does not mean that actually existing trade unions are able and willing to take on such a transformatory role." ${ }^{32}$

If a revolutionary unionism is to take root, it will have to encompass a new, broader definition of the working class, one that extends membership and organizing to unwaged labour, as well as to self-employed, unemployed, and precariously employed people. ${ }^{33}$ To become "vehicles of socialist advance," as Hyman describes it, unions will have to adopt and espouse an openly radical critique of capitalism. This should not be all that difficult given the general erosion of the quality of life for workers globally, the imminence of environmental catastrophe, and the growing inequality within every nation. There are good historic examples of unions that have maintained a radical critique of capitalism while operating successfully for members. In North America these include the Knights of Labor, the Industrial Workers of the World, the One Big Union, and communist unions and locals in the 1930s. There are grounds to argue that it was the very existence of these revolutionary unions and other left forces that made the gains of business unionism and social democracy possible in the first place. A study of business response to social reforms concluded that capital actively supports social reform only when under revolutionary threat. According to Thomas Paster, "employers are protagonists of social protection in revolutionary situations, consenters in reformist situations, and opponents if neither situation exists." ${ }^{34}$ Revolutionary challenges were defined as those strong enough to cause political instability and create fear of expropriation.

Currently, revolutionary unions are already demonstrating the ability to link with the broader working class in struggle. Beltran Roca and Iban DiazParra studied the cooperation between the anarcho-syndicalist General Confederation of Labour (CGT) and the M15 (indignados) social movement in Spain to promote a mass strike in which workers, the unemployed, retired workers, housewives, precarious workers, and students were involved. ${ }^{35}$ They observe how cooperation between the new social movement M15 and the CGT has shifted the social movement to the left.

\section{Hyman, "The Real Richard Hyman," 153.}

33. I like Bryan D. Palmer's broad-stroke definition: "Class is about being expropriated from ownership of all manner of means of production, and those without, or mostly without, such 'property,' be their wages high, low, secure, precarious, or even non-existent, constitute the working class." Palmer, "Approaching Working-Class History as Struggle: A Canadian Contemplation; a Marxist Meditation," Dialectical Anthropology 42, 4 (2018): 444, https://doi. org/10.1007/s10624-018-9503-z.

34. Paster, "Business and Welfare State Development: Why Did Employers Accept Social Reforms?," World Politics 65, 3 (2013): 418.

35. Roca \& Diaz-Parra, "Blurring the Borders between Old and New Social Movements: The M15 Movement and the Radical Unions in Spain," Mediterranean Politics 22, 2 (2017): 218-237. 
Truly revolutionary unions are needed to broaden the labour movement enough to organize the vast majority of working-class people who cannot be successfully integrated into a business union model and to create a vehicle capable of confronting capitalism. Yet, can existing unions engage in this struggle, or do new organizations have to be built?

\section{How Could a Revolutionary Union Movement Be Built?}

THE QUESTION IS HOW to go about encouraging the rebirth of a revolutionary union movement. This does not necessarily require a hard break with the present. The labour movement knows it is in trouble: the apocalyptic "organize or die" language, the frantic mergers, and the internecine raiding, all against an awareness of diminishing membership, make that clear. It is possible that some progressive unions might shift to an anti-capitalist analysis and engage in more radical projects if they can do so without triggering retaliation from the state. This is a substantial threat, since the capacity of the state to punish unions is immense. For example, the Alberta government has played on fears of organizational dissolution and bankruptcy by threatening (and levying through the courts) truly massive fines against public-sector unions, and at one point gave cabinet the ability to decertify unions.

However, there are still transformational actions unions can take that will move them from acquiescence to opposition to capitalism without putting union legality at risk. As one of the few working-class organizations that amass capital (for example, the Fédération des travailleurs et travailleuses du Québec, or FTQ, has over \$7 billion in its Solidarity Fund and most unions have substantial strike or contingency funds), unions could engage in projects to build the new society in the shell of the old. Instead of providing union funds to businesses through venture capital projects, or leaving it in guaranteed investment certificates in banks or credit unions, unions could use their money to fund worthwhile non-capitalist projects. Unions could, for instance, build and operate their own seniors' centres and childcare centres. Their own members could staff and collectively administer the centres - gaining invaluable experience with workers' control of operations. Critically, union-owned and operated seniors' or daycare facilities could provide empirical evidence about optimal care practices and best-outcomes staffing levels. This would not only be good for workers and their clients, but would also expose the weaknesses of for-profit operations. This would be a win-win for the working class.

Unions have built housing for their members in the past. They could do so again by building social or co-housing owned in perpetuity by a union trust, thereby letting their members escape the real estate game. Unions could support cooperatives and mutual aid societies that benefit their members and meet broader community needs. These kinds of projects kill two birds with one stone. Workers and unions need to develop the abilities to run their own enterprises in their own interest, and workers need to experience first-hand 
the benefits of cooperative enterprise. If a socialist society is the objective, then it is essential to build the capacity for worker control. Leo Panitch and Sam Ginden warn that to "underplay how far workers' actual capacities have been constricted under capitalism" is a huge risk for plans for social transformation under a Corbyn government in Britain. ${ }^{36}$ That capacity to plan, organize, and operate a multitude of different kinds and sizes of operations is exactly what these kinds of union projects could nurture.

The labour movement could also, with little sacrifice, bankroll allies in social movements - without trying to control or manipulate them. None of these kinds of actions would directly challenge the system, but they would provide union members and the broader working-class community a basic experience with non-capitalist relations. People need to see the possibilities of socialist, cooperative organization before they can struggle for socialisminstead of struggling against capitalism.

Furthermore, a radicalization of the union movement would signal a sea change in the relationship between the organized working class and its various allies and communities. This should stimulate conversations and debates about new forms of left strategies and tactics in pursuit of a socialist future and, in doing so, help reinvigorate the left.

\section{The Need for Broad Discussion in the Labour Movement}

One thing is Certain. A new unionism is only possible if workers and labour/left activists seriously discuss it. Just considering the possibility of a radical union project is the first step. In this, I think left academics, and particularly labour historians, have a critical role to play. If the labour movement is going to evolve, it must engage in debate and internal struggle. To quote Hyman, "in this process, the most useful contribution of academics is to elaborate the right questions, not to short-circuit the collective search for answers." ${ }^{37}$

To this end, a national conference should be organized with the theme "Rediscovering Labour Radicalism: Can Unions Change the World?" This could at least launch the discussion. AU PE President Smith feels that this conversation is overdue: "the labour movement needs to rediscover its radical roots, and this kind of conference would be an important first step." ${ }^{8}$ The target of such a conference would be union leaders and militants, labour historians and other academic activists, anti-capitalists, and citizens interested in real social change. Without limiting an agenda, discussions could address what unions could do to go beyond the business union model - in structure,

36. Leo Panitch \& Sam Gindin, "In and Against the State," The Bullet, 24 October 2018, https:// socialistproject.ca/2018/10/in-and-against-the-state.

37. Hyman, "The Real Richard Hyman," 155.

38. Smith, personal communication, 11 September 2018. 


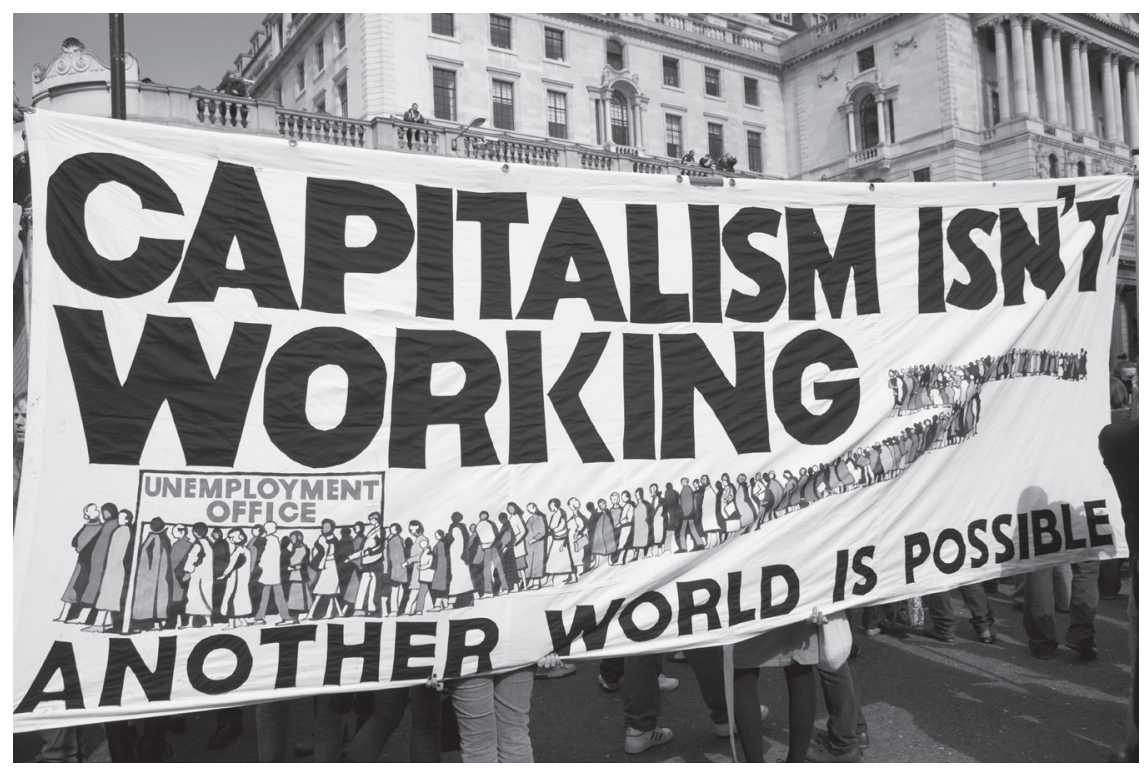

Anti-capitalism protestors holding a banner during a demonstration outside the Bank of England, 1 April 2009.

Roger Hutchings/Alamy Stock Photo.

purpose, and action. How far could current unions evolve? At what point should a new union that acts and organizes outside of the legal industrial relations system be considered? How would such a union deal with challenges from the state when organizing on the fringes of - or on the outside of - the industrial legal system? This is a crucial part of the discussion because it seems highly probable that, should the union movement embrace a radical program, the more successful the program is, the greater the likelihood of state opposition. Roger Marwick suggests that if 21st-century socialism actually threatens the global elite then it will "face 'the furies' of state power." ${ }^{39}$

That there will be obstacles to any revolutionary union program - by both capital and incorporated unions - goes without saying. The immediate objective, however, is to initiate a discussion about the need for a new radical unionism, not to predetermine its final shape. What is needed now in the labour movement, as a starting point, is the courage to speak and act on the environment, unwaged labour, precarious work, globalization, and our decaying social fabric. It is through such struggles that we can build a labour movement based upon a rejection of capitalism, dedicated to building a new society, and able to challenge neoliberalism. 